\title{
Blir retningslinjene for fosterdiagnostisk ultralyd fulgt?
}

\begin{abstract}
Sammendrag
Bakgrunn. Bioteknologiloven skiller mellom ultralyd i den alminnelige svangerskapsomsorgen og ultralyd som fosterdiagnostikk. Loven kritiseres for å være uklar og vanskelig å etterleve i klinisk praksis. Hensikten med denne studien var å undersøke om leger fulgte retningslinjene for bioteknologiloven da de vurderte kasuistikker med kvinner som ønsket tidlig ultralyd med fosterdiagnostikk.
\end{abstract}

Materiale og metode. Vi ba privatpraktiserende gynekologer, leger ved fostermedisinske sentre samt jurister og konsulenter i Avdeling for bioteknologi og helserett i Helsedirektoratet om å vurdere seks fiktive kasuistikker med kvinner som ønsket tidlig ultralyd.

Resultater. Vi mottok svar fra 64/130 (49\%) privatpraktiserende gynekologer, $22 / 27$ ( $81 \%$ ) leger ved fostermedisinske sentre og 5/12 (42\%) respondenter i Helsedirektoratet. Bare 29/86 (34\%) av alle legene svarte at de forholder seg strengt til alderskriteriet på 38 år. 33/64 (52\%) privatpraktiserende gynekologer ville måle nakkeoppklaring selv, og 43/64 (67\%) har henvist til fosterdiagnostikk på indikasjonen «angst og uro». 16/22 (73\%) leger ved fostermedisinske sentre mente at angst og uro er indikasjon for fosterdiagnostikk. Alle respondentene i Helsedirektoratet svarte at dette ikke er korrekt i henhold til retningslinjene.

Fortolkning. Flertallet av legene forholdt seg ikke strengt til retningslinjene da de vurderte kasuistikkene, og retningslinjene ble fortolket ulikt av leger og respondenter i Helsedirektoratet.

\section{Kjerstine Røe}

kjerr@stud.ntnu.no

Norges teknisk-naturvitenskapelige universitet

Kjell Åsmund Salvesen

Nasjonalt senter for fostermedisin

St. Olavs hospital

og

Institutt for laboratoriemedisin, barne- og kvinnesykdommer

Norges teknisk-naturvitenskapelige universitet

\section{Torbjørn Moe Eggebø}

Kvinne- og barneklinikken

Stavanger universitetssjukehus

Lov om humanmedisinsk bruk av bioteknologi (bioteknologiloven) trådte i kraft 1. januar 2004 (1). Loven definerer fosterdiagnostikk som undersøkelse av føtale celler, foster eller en gravid kvinne med det formål å få informasjon om fosterets genetiske egenskaper eller for å påvise eller utelukke sykdom eller utviklingsavvik hos fosteret (1).

I Norge har fem sykehus godkjenning for å gjøre fosterdiagnostikk. Indikasjonene er beskrevet i retningslinjene for bruk av ultralyd i svangerskapet fra 2004 og presisert i brosjyren Informasjon til gravide om fosterdiagnostikk fra 2005 (ramme 1) (2, 3).

Ultralyd i uke 11-13 med måling av nakkeoppklaring (fig 1) og kombinert ultralyd og blodprøve (KUB-test) regnes som fosterdiagnostiske undersøkelser. Nakkeoppklaringen skyldes ødem i nakken hos fosteret, og blodprøvene som tas av mor og inngår i KUB-testen måler konsentrasjonen av humant choriongonadotropin (HCG) og svangerskapsrelatert plasmaprotein A (pregnancyassociated plasma protein A, PAPP-A). KUB-test predikerer sannsynligheten for kromosomavvik eller utviklingsavvik hos fosteret (4-6), og metoden ble innført for å unngå komplikasjoner knyttet til invasiv prøvetaking (7). Når ultralydundersøkelser utføres med mistanke om genetisk sykdom, skal det først gis genetisk veiledning. Ultralydundersøkelser i den alminnelige svangerskapsomsorgen, dvs. rutineundersøkelsen i andre trimester og undersøkelser på medisinske indikasjoner, anses ikke som fosterdiagnostikk og omfattes ikke av loven $(1,2)$.

Bioteknologiloven er under revisjon og diskuteres både $\mathrm{i}$ offentlige organer og $\mathrm{i}$ mediene (8-10). Allerede i 2004 ble loven karakterisert som uklar, og det ble spådd at forskriftene om ultralyd som fosterdiagnostikk ikke ville bli fulgt i klinisk praksis (11). Et hovedproblem ved loven er skillet mellom ultralyd som ledd i den alminnelige svangerskapsomsorgen og ultralyd som fosterdiagnostikk. Andre kontroversielle spørsmål er om «angst og uro» er indikasjon for fosterdiagnostikk, hvordan alderskriteriet skal tolkes, og hvordan uklare indikasjoner som «vanskelig livssituasjon» skal håndteres.

Hensikten med denne studien var å undersøke om leger fulgte retningslinjene for bioteknologiloven da de vurderte fiktive kasuistikker om kvinner som ønsket tidlig ultralyd med fosterdiagnostikk.

\section{Materiale og metode}

Vi konstruerte seks kasuistikker med kvinner som ønsket ultralyd med fosterdiagnostikk (ramme 2) og knyttet tre sett med spørsmål til kasuistikkene tilpasset de ulike respondentgruppene. Spørsmålene hadde forhåndsgitte svaralternativer. Retningslinjene for bruk av ultralyd i svangerskapet var forutsatt kjent og ble ikke presentert sammen med spørreskjemaet. Overskriftene til kasuistikkene (ramme 2) var ikke med i spørreskjemaet. Datainnsamlingen ble gjennomført i tidsrommet oktober-desember 2011.

Spørreskjema ble sendt til seksjonslederne ved alle fostermedisinske sentre i Norge (Tromsø, Trondheim, Bergen, Stavanger og Oslo). Lederne distribuerte skjemaet til alle leger som vurderer henvisninger ved sitt senter. Kasuistikkene ble presentert som henvisninger, og legene ble bedt om å besvare spørsmålene som om henvisningen angikk en virkelig pasient. Spørreskjemaet ble besvart anonymt.

Spørreskjema ble også sendt til alle spesialister i fødselshjelp og kvinnesykdommer (gynekologer) som på det gitte tidspunktet var medlemmer av Den norske legeforening og som hadde oppgitt å være privatpraktiserende i spesialiteten. Gynekologene ble bedt om å besvare spørsmålene ut fra hva de ville gjort om dette var en ekte pasient. Spørreskjemaet ble besvart anonymt. Spørreskje-

\section{Hovedbudskap}

- Retningslinjene for bruk av ultralyd i svangerskapet er uklare og åpner for subjektive vurderinger

- Noen leger svarte at de ville utført fosterdiagnostikk også i tilfeller der retningslinjene tydelig sier at det er ulovlig 


\section{Ramme 1}

Indikasjoner for fosterdiagnostikk Fosterdiagnostikk er regulert av bioteknologiloven (1). Ultralydunders $ø$ kelse med måling av nakkeoppklaring og kombinert ultralyd og blodprøve (KUB-test) regnes som fosterdiagnostikk. Dette er indikasjonene for fosterdiagnostikk slik de er beskrevet i Helsedirektoratets informasjonsbrosjyre Informasjon til gravide om fosterdiagnostikk (3).

- Gravide som er 38 år eller eldre ved termin

- Gravide, i de tilfeller der kvinnen selv eller hennes partner

- tidligere har fått et barn eller foster med alvorlig sykdom eller utviklingsavvik (f.eks. kromosomfeil)

- har økt risiko for alvorlig sykdom hos fosteret og denne tilstanden kan påvises (f.eks. en del arvelige sykdommer)

- bruker medisiner som kan skade fosteret (f.eks. ved epilepsi hos mor)

- Gravide som har fått påvist tegn til utviklingsavvik hos fosteret ved en ultralydundersøkelse

- I spesielle tilfeller, gravide som er i en vanskelig livssituasjon og mener at de ikke vil klare den ekstra belastningen et sykt eller funksjonshemmet barn kan medføre

ma ble også sendt til en kontaktperson i Avdeling for bioteknologi og helserett i Helsedirektoratet. Vedkommende distribuerte det videre til jurister og konsulenter som arbeider med juridiske, helserelaterte problemstillinger i avdelingen.

For de tre første kasuistikkene ble legene spurt om de ville tilbudt kvinnen undersøkelse, eventuelt hva slags. Respondentene i Helsedirektoratet ble spurt om kvinnene hadde rett til fosterdiagnostikk etter retningslinjene, og i kasuistikk 2 ble de spurt om de mente at leger som gjør fosterdiagnostikk på bakgrunn av denne problemstillingen, bryter loven. Alle respondentene ble spurt om tolking av alderskriteriet, og alle

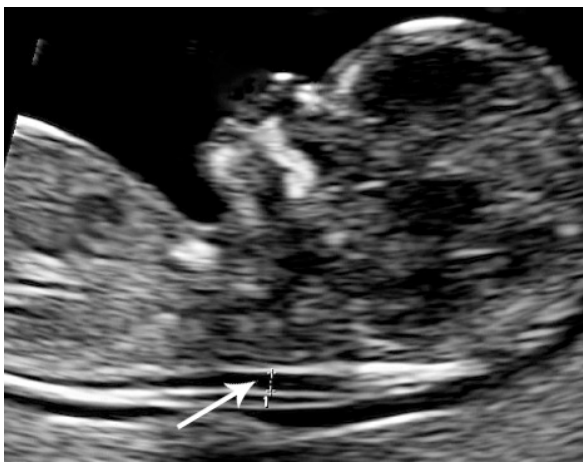

Figur 1 Ultralydbilde som viser sted for måling av nakkeoppklaring hos foster. Foto T. M. Eggebø legene ble spurt om de praktiserer slingringsmonn når det gjelder aldersgrensen.

For de tre siste kasuistikkene ble de privatpraktiserende gynekologene spurt om de ville henvist kvinnen videre til et fostermedisinsk senter. I kasuistikk 4 spurte vi om de i så fall ville målt nakkeoppklaringen først, og for kasuistikk 5 og 6 ble de spurt om indikasjon. Legene ved de fostermedisinske sentrene ble spurt om hva slags undersøkelse de ville tilbudt kvinnen, om de mente at hun har rett til fosterdiagnostikk etter retningslinjene, og i så fall på hvilken indikasjon. Respondentene i Helsedirektoratet ble spurt om kvinnene har rett til fosterdiagnostikk etter retningslinjene. Uavhengig av kasuistikkene ble alle spurt om hvordan de forholder seg til angst og uro som indikasjon for fosterdiagnostikk.

\section{Statistikk}

Eventuelle forskjeller i svar mellom de ulike sentrene, yrkesgruppene og ut fra kjønnsforskjeller ble undersøkt med Fishers eksakte test og khikvadrattest. Betydningen av respondentenes alder er undersøkt med logistisk regresjon med kategoriske svar som avhengig variabel og alder som forklaringsvariabel. Data ble analysert med statistikkprogrammet PASW 18.0.

\section{Resultater}

Vi mottok svar fra 22 (81\%) av 27 leger som vurderer henvisninger til fosterdiagnostikk ved de godkjente sentrene. I Tromsø, Trondheim og Bergen er det bare spesialister i fødselshjelp og kvinnesykdommer som vurderer henvisninger. I Stavanger og Oslo blir henvisninger også vurdert av spesialister $i$ medisinsk genetikk. 19 av respondentene var spesialister i fødselshjelp og kvinnesykdommer og tre var spesialister i medisinsk genetikk. Gjennomsnittsalderen var 51 år, $14(64 \%)$ var menn og 14 (64\%) hadde internasjonal godkjenning til å måle nakkeoppklaring fra Fetal Medicine Foundation (FMF) (12). Det var ingen signifikante forskjeller i hvordan henvisningene ble vurdert ved de ulike fostermedisinske sentrene, mellom gynekologer og genetikere, mellom menn og kvinner, eller ut fra alder.

Vi mottok svar fra $64(49 \%)$ av 130 privatpraktiserende gynekologer. Gjennomsnittsalderen var 56 år, og 33 (52\%) var kvinner. Det var ingen signifikante forskjeller relatert til kjønn eller alder for hvordan privatpraktiserende gynekologer vurderte alderskriteriet og måling av nakkefold, men flere kvinner enn menn henviste til fosterdiagnostikk med angst og uro som indikasjon.

Av 12 mulige respondenter i Helsedirektoratet mottok vi svar fra fem $(42 \%)$. Fire av respondentene var jurister og én var konsulent.

På den første kasuistikken (tolking av alderskriteriet) ville 29 (45\%) privatpraktiserende gynekologer gjort en orienterende ultralydundersøkelse og henvist ved mistanke, og $11(17 \%)$ ville målt nakkeoppklaringen selv. $14(64 \%)$ leger ved de fostermedisinske sentrene ville gjort fosterdiagnostikk (måling av nakkeoppklaring eller KUBtest). Alle respondentene i Helsedirektoratet svarte at kvinnen i kasuistikken ikke har rett til fosterdiagnostikk ifølge retningslinjene.

Alle legene ved de fostermedisinske sentrene mente at aldersgrensen på 38 år gjelder ved forventet termin, mens fire $(6 \%)$ privatpraktiserende gynekologer mente at kvinnen må være fylt 38 år ved undersøkelsestidspunktet. Bare 29 (34\%) av alle legene svarte at de forholdt seg helt strengt til aldersgrensen på 38 år.

På den andre kasuistikken (kollega) ville $45(70 \%)$ privatpraktiserende gynekologer gjort en orienterende ultralyd og henvist ved mistanke, mens $12(19 \%)$ ville målt nakkeoppklaring selv. Ved de godkjente sentrene ville $13(59 \%)$ målt nakkeoppklaringen, mens én $(5 \%)$ ville utført KUB-test. Alle respondentene i Helsedirektoratet svarte at kvinnen ikke har rett til fosterdiagnostikk, og fire $(80 \%)$ mente at leger som gjør fosterdiagnostikk i en slik situasjon bryter loven.

På den tredje kasuistikken (utenlandsk kvinne) ville $30(47 \%)$ privatpraktiserende gynekologer gjort en orienterende ultralyd og henvist ved mistanke og 13 (20\%) ville målt nakkeoppklaringen selv. Ved de godkjente sentrene ville sju (32\%) tilbudt fosterdiagnostikk. Alle respondentene i Helsedirektoratet svarte at kvinnen ikke har rett til fosterdiagnostikk.

På den fjerde kasuistikken (tilfeldig funn) svarte $33(52 \%)$ privatpraktiserende gynekologer at de først ville henvist kvinnen dersom de selv hadde målt at nakkeoppklaringen var økt, mens 25 (39\%) ville henvist videre basert på inntrykket uten noen egen måling. $21(95 \%)$ av legene ved de godkjente sentrene ville tilbudt fosterdiagnostikk (måling av nakkeoppklaring eller KUBtest), mens 18 (82\%) mente at kvinnen har rett til fosterdiagnostikk etter retningslinjene. Fire $(80 \%)$ av respondentene fra Helsedirektoratet svarte at kvinnen har rett til fosterdiagnostikk etter retningslinjene.

På den femte kasuistikken (angst og uro) ville $43(67 \%)$ privatpraktiserende gynekologer henvist kvinnen til et fostermedisinsk senter. $34(53 \%)$ ville brukt angst og uro som indikasjon. $16(73 \%)$ av legene ved de godkjente sentrene ville tilbudt fosterdiagnostikk (måling av nakkeoppklaring eller KUB-test). Ni (41\%) mente at hun har rett til fosterdiagnostikk ifølge retningslinjene, og ni $(41 \%)$ mente at angst og uro var indikasjon. Alle respondentene fra Helsedirektoratet svarte at hun ikke har krav på fosterdiagnostikk.

Tabell 1 viser hvordan respondentene forholder seg til angst og uro som indikasjon for fosterdiagnostikk. I gruppen av privatpraktiserende gynekologer var det signifikant flere kvinner $(27 / 33$ vs. $15 / 27, p=0,03)$ som svarte at de har henvist til fosterdiagnostikk med angst og uro som indikasjon. 
På den sjette kasuistikken (vanskelig livssituasjon) ville 30 (47\%) privatpraktiserende gynekologer henvist videre til fosterdiagnostikk og sju (11\%) mente at vanskelig livssituasjon var indikasjon. $13(59 \%)$ av legene ved de godkjente sentrene ville tilbudt fosterdiagnostikk (måling av nakkeoppklaring eller KUB-test). Åtte (36\%) mente at vanskelig livssituasjon var indikasjon. Ti $(45 \%)$ svarte at hun har rett til fosterdiagnostikk ifølge retningslinjene. Fire $(80 \%)$ av respondentene fra Helsedirektoratet svarte at hun har rett til fosterdiagnostikk.

\section{Diskusjon}

Resultatene viser at retningslinjene for ultralyd som fosterdiagnostikk ikke ble enhetlig tolket og fulgt da leger vurderte de fiktive kasuistikkene. Alderskriteriet ble ikke overholdt, og kvinner fikk innvilget fosterdiagnostikk uten indikasjon. Mange privatpraktiserende gynekologer svarte at de ville målt nakkeoppklaringen selv om de ikke har lov til å utføre fosterdiagnostikk. Det kan være vanskelig å skille mellom ultralyd i den alminnelige svangerskapsomsorgen og ultralyd som fosterdiagnostikk.

Resultatene indikerer holdninger til fiktive kasuistikker, og spørsmålet om hvilke undersøkelser kvinner i det virkelige liv ville fått, er strengt tatt ubesvart. Vi antar likevel at det er en sammenheng mellom håndtering $\mathrm{av}$ kasuistikker og klinisk praksis. Spørsmålene om håndtering av alderskriteriet og angst og uro som indikasjon for fosterdiagnostikk ble dessuten stilt uavhengig av kasuistikkene. Disse resultatene tyder på at mange leger ikke praktiserer aldersgrensen strengt og at kvinner får tilbud om ultralyd med fosterdiagnostikk på angst og uro som indikasjon også i daglig klinisk praksis.

Den første kasuistikken illustrerer problemer knyttet til tolking av alderskriteriet. Kvinner på 37 år og 38 år har omtrent samme risiko for å få barn med kromosomfeil (5). Det finnes ikke noen god begrunnelse basert på risiko for at bare kvinner på 38 år skal få tilbud om fosterdiagnostikk. I den aktuelle kasuistikken var kvinnen 37 år og to måneder ved tidspunktet for undersøkelsen. Hun ville vært 37 år og ni måneder ved antatt termin. Det står ikke presisert i retningslinjene for bruk av ultralyd i svangerskapet om aldersgrensen gjelder ved undersøkelsen eller ved forventet termin (2). I informasjonsbrosjyren til gravide om fosterdiagnostikk og i veilederen fra Norsk gynekologisk forening står det imidlertid presisert 38 år ved termin $(3,13)$. Alle legene ved de fostermedisinske sentrene var klar over denne presiseringen. Likevel var det bare et fåtall av legene som svarte at de forholder seg strengt til alderskriteriet, og kvinner som er nær 38 år ved forventet termin får trolig ofte tilbud om fosterdiagnostikk.

Over halvparten av legene ved de godkjente sentrene ville tilby kollegaen i kasui- stikk to ultralyd som fosterdiagnostikk. Fire av fem respondenter fra Helsedirektoratet mente at disse legene bryter norsk lov. Kun én av legene ville tilbudt kollegaen KUBtest, resten ville gjort ultralyd med måling av nakkeoppklaring. Det kan se ut som at legene anser det som en mindre alvorlig overtredelse av regelverket dersom man utelater blodprøvene.

Kvinner fra land der alle får tilbud om fosterdiagnostikk kan ha vanskelig for å godta en streng norsk lovgiving. De reiser til hjemlandet for undersøkelse hvis de ikke får tilbud i Norge, og mange kommer tilbake med et prøvesvar som det blir opp til norske leger å følge opp. Det kan være årsaken til at en tredel av legene ved de fostermedisinske sentrene ville innvilge fosterdiagnostikk i kasuistikk 3.

\section{Ramme 2}

Kasuistikkene som ble forelagt privatpraktiserende gynekologer, leger ved fostermedisinske sentre og konsulenter i Helsedirektoratet

- Kasuistikk 1 - tolking av alderskriteriet i bioteknologilovens forskrifter Kvinnen er gravid i svangerskapsuke 8. Hun er tredjegangsfødende, tidligere frisk, bruker ingen medikamenter og har ingen spesielle sykdommer i familien. Hun fylte 37 år for to måneder siden og ønsker på grunn av sin alder tidlig ultralyd for å utelukke kromosomavvik hos fosteret.

- Kasuistikk 2 - vil en kollega få annen behandling enn andre gravide? Kvinnen er gravid i svangerskapsuke 8. Hun er lege i spesialisering ved gynekologisk avdeling og ønsker tidlig ultralydundersøkelse. Hun er 34 år gammel, førstegangsgravid og har ingen spesielle risikofaktorer knyttet til svangerskapet.

- Kasuistikk 3 - ulik praksis i europeiske land og betydning for norsk praksis En 35 år gammel tredjegangsfødende kvinne fra England er gravid i svangerskapsuke 9. Hun har bodd i Norge i tre år. I sine to tidligere normale svangerskap fikk hun fosterdiagnostikk i hjemlandet. Nå ønsker hun tidlig ultralydundersøkelse i det aktuelle svangerskapet i Norge. Kvinnen sier at hun vil reise til England for undersøkelse dersom hun ikke får den utført her.

- Kasuistikk 4 - tilfeldig funn ved undersøkelse på klinisk indikasjon Kvinnen er 35 år gammel, gravida sju og para tre. Hun har hatt tre ukompliserte svangerskap og fødsler, én provosert abort og to tidligere spontanaborter. Hun har vært til tidlig ultralydundersøkelse hos privat gynekolog på grunn av vaginalblødning. Ved undersøkelsen ble det sett et vitalt foster tilsvarende svangerskapsuke 11. Gynekologen fikk inntrykk av lett økt nakkeoppklaring og informerte om dette. Kvinnen ble redd og ønsket henvisning til et fostermedisinsk senter. Ut ifra et vedlagt bilde mente legen ved sykehuset at nakkeoppklaringen virket normal.

- Kasuistikk 5 - angst og uro som indikasjon for fosterdiagnostikk Kvinnen er 24 år gammel og førstegangsgravid i svangerskapsuke 7. Hun har slitt med muskelog skjelettsmerter siden 19-årsalderen og har fått diagnosen fibromyalgi. Hun arbeider i $70 \%$ stilling i et bakeri og er $30 \%$ uføretrygdet. Hun bruker ingen faste medikamenter, men tar paracetamol og ibuprofen mot smertene ved behov. Kvinnens søster fødte en gutt med trisomi 21 for fire år siden. Hun er nå selv svært bekymret for at hun skal føde et sykt barn. Legen har forklart at søsterens barn ikke øker hennes risiko for å få barn med kromosomfeil og at medikamentene hun har brukt ikke er farlige. Hun klarer ikke å slå seg til ro med denne informasjonen og ønsker henvisning til fosterdiagnostikk.

- Kasuistikk 6 - vanskelig livssituasjon som indikasjon for fosterdiagnostikk Kvinnen er 31 år, annengangsfødende og gravid i svangerskapsuke 6. Paret har en seks år gammel datter. Mannen er arbeidsledig. Hun er hjelpepleier i full stilling på et sykehjem og har mye nattarbeid. Hun er overvektig og bruker Selo-Zok $50 \mathrm{mg} \times 1$ pga. hypertensjon. I tillegg bruker hun Paralgin forte daglig for spenningshodepine. Paret ønsker sterkt et nytt barn, men mener at de ikke kan greie belastningen med å få et sykt barn verken praktisk eller økonomisk. De er særlig bekymret for å få et funksjonshemmet barn og er redd for at medikamentene hun bruker kan ha gjort skade. Paret ønsker en tidlig ultralydundersøkelse for å utelukke fosteravik. 
Tabell 1 Respondentenes svar på spørsmål om angst/uro som indikasjon for fosterdiagnostikk

\begin{tabular}{|c|c|c|c|c|c|c|}
\hline & \multicolumn{3}{|c|}{$\begin{array}{c}\text { Har du henvist til } \\
\text { fosterdiagnostikk } \\
\text { på indikasjonen angst og uro? }\end{array}$} & \multicolumn{3}{|c|}{$\begin{array}{c}\text { Mener du at angst og uro } \\
\text { gir indikasjon } \\
\text { for fosterdiagnostikk? }\end{array}$} \\
\hline & $\mathrm{Ja}$ & $\mathrm{Nei}$ & Ikke svart & $\mathrm{Ja}$ & Nei & Ikke svart \\
\hline $\begin{array}{l}\text { Privatpraktiserende } \\
\text { gynekologer }\end{array}$ & 43 & 20 & 1 & & & \\
\hline $\begin{array}{l}\text { Leger ved } \\
\text { fostermedisinske sentre }\end{array}$ & & & & 16 & 5 & 1 \\
\hline $\begin{array}{l}\text { Jurister og konsulenter } \\
\text { i Helsedirektoratet }\end{array}$ & & & & & 5 & \\
\hline
\end{tabular}

kvent. Én årsak kan være usikkerhet blant norske leger for om de bryter loven dersom de måler fosterets nakkeoppklaring.

I en kronikk i Tidsskrift for Den norske legeforening i 2009 argumenteres det for at god og kvalitetssikret informasjon er en forutsetning for at reflekterte og ansvarlige gravide skal kunne ta informerte og autonome valg (14). Skillet mellom ultralyd som ledd i den alminnelige svangerskapsomsorgen og ultralyd som fosterdiagnostikk vanskeliggjør en slik målsetting. Mens det er strenge krav til informasjon og veiledning i forkant av fosterdiagnostiske undersøkelser, gjelder denne informasjonsplikten ikke for undersøkelser på medisinsk indikasjon.

Ifølge retningslinjene er angst og uro medisinsk indikasjon for ultralyd i den alminnelige svangerskapsomsorgen, men ikke for fosterdiagnostikk. Respondentene fra Helsedirektoratet mente at kvinnen i kasuistikk fem ikke har krav på fosterdiagnostikk. I praksis vil mange leger ved de godkjente sentrene likevel tilby en slik kvinne fosterdiagnostikk med angst og uro som indikasjon. Angst og uro fungerer dermed som en bakvei inn til fosterdiagnostikk. Resultatene våre tyder på at det er usikkerhet blant norske leger om angst og uro er en indikasjon for fosterdiagnostikk. Vi ser også en forskjell mellom antallet leger $(n=16)$ ved de godkjente sentrene som innvilger fosterdiagnostikk og antallet $(n=9)$ som mener at den samme kvinnen har rett til fosterdiagnostikk etter retningslinjene. Det betyr at mange leger vil kunne innvilge fosterdiagnostikk selv om de mener at kvinnen ikke har rett til det ifølge retningslinjene.

Å definere hva som er en «vanskelig livssituasjon» er problematisk. Er det paret selv og/eller henvisende lege som skal vurdere dette, eller er det legen ved det fostermedisinske senteret som skal bestemme? Subjektive vurderinger blir lagt til grunn, og kasuistikken illustrerer hvor varierende utfallet kan bli. Respondentene fra Helsedirektoratet var relativt samstemte om at denne kvinnen har rett til fosterdiagnostikk, men under halvparten av legene ved de godkjente sentrene var enige. Våre resultater tyder på at leger i større grad enn respondentene i Helsedirektoratet vil godta fostermedisinsk ultralyd på indikasjonen «angst og uro», mens situasjonen er motsatt for «vanskelig livssituasjon».

Det er blitt hevdet at det er lettere å få utført fosterdiagnostikk i Midt- og Øst-Norge enn $\mathrm{i}$ andre deler av landet. Rapporten fra Helsedirektoratet fra 2011 viste en ulik fordeling mellom fylkene, og antall fosterdiagnostiske undersøkelser relatert til antallet gravide over 38 år i ulike fylker illustrerte det. I 2009 var dette forholdet 2,4 i SørTrøndelag, 1,8 i Oslo, 1,1 i Rogaland, og 0,6 i Aust-Agder (8). I vår undersøkelse fikk vi ikke frem ulikheter i vurderingene mellom de fosterdiagnostiske sentrene.

$\mathrm{Vi}$ konkluderer med at mange leger ikke fulgte retningslinjene for bioteknologiloven da de vurderte de fiktive kasuistikkene. Det var også uenighet i fortolkning av retningslinjene mellom leger og respondenter fra Helsedirektoratet.

\section{Kjerstine Røe (f. 1982)}

er medisinstudent ved Norges teknisk-naturvitenskapelige universitet og har bachelorgrad i filosofi fra Universitet i Bergen.

Forfatter har fylt ut ICMJE-skjemaet og oppgir ingen interessekonflikter.

\section{Kjell Åsmund Salvesen (f. 1958)}

er spesialist i fødselshjelp og kvinnesykdommer med spesialkompetanse i fostermedisin. Han er professor ved Norges teknisk-naturvitenskapelige universitet og Lund universitet og overlege ved Nasjonalt Senter for fostermedisin.

Forfatter har fylt ut ICMJE-skjemaet og oppgir ingen interessekonflikter.

\section{Torbjørn Moe Eggebø (f. 1955)}

er spesialist i fødselshjelp og kvinnesykdommer og forsvarte ph.d.-graden om bruk av ultralyd under fødsel i 2009. Han er seksjonsoverlege ved fødeavdelingen og ultralydlaboratoriet ved Stavanger universitetssjukehus og medlem av Editorial board i Acta Obstetrica et Gynecologica Scandinavica.

Forfatter har fylt ut ICMJE-skjemaet og oppgir ingen interessekonflikter.

\section{Litteratur}

1. Lov om humanmedisinsk bruk av bioteknologi (bioteknologiloven). www.lovdata.no/all/ hl-20031205-100.html (23.3.2012).

2. Veiledende retningslinjer for bruk av ultralyd i svangerskapet. Bruk av ultralyd i den alminnelige svangerskapsomsorgen og i forbindelse med fosterdiagnostikk. IS-23/2004. Oslo: Helsedirektoratet, 2004. www.helsedirektoratet.no/ publikasjoner/veiledende-retningslinjer-for-brukav-ultralyd-i-svangerskapet/Sider/default.aspx (23.3.2012)

3. Informasjon til gravide om fosterdiagnostikk IS-1313. Oslo: Helsedirektoratet, 2005. http://helsedirektoratet.no/publikasjoner/ informasjon-til-gravide-om-fosterdiagnostikk/ Sider/default.aspx (23.3.2012)

4. Conner P. Westgren M, Marsk A et al. Combined ultrasound and biochemistry for risk evaluation in the first trimester: the Stockholm experience of a new web-based system. Acta Obstet Gynecol Scand 2012; 91: 34-8

5. Nicolaides KH, Sebire NJ, Snijders RJM. The 11-14 week scan: the diagnosis of fetal abnormalities. New York, NY: Parthenon, 1999.

6. Snijders RJ, Sebire NJ, Nayar R et al. Increased nuchal translucency in trisomy 13 fetuses at 10-14 weeks of gestation. Am J Med Genet 1999 86: $205-7$

7. Tabor A, Alfirevic Z. Update on procedure-related risks for prenatal diagnosis techniques. Fetal Diagn Ther 2010; 27: 1-7.

8. Evaluering av bioteknologiloven - status og utvikling på fagområdene som reguleres av loven. IS-1897. Oslo: Helsedirektoratet, 2011. www.helsedirektoratet.no/publikasjoner/ evaluering-av-bioteknologiloven-status-ogutvikling-pa-fagomradene-som-reguleres-avloven/Sider/evaluering-av-bioteknologilovenstatus-og-utvikling-pa-fagomradene-somreguleres-av-loven.aspx (23.3.2012).

9. Lauvrak V, Norderhaug IN, Hagen $G$ et al. Tidlig ultralyd i svangerskapsomsorgen. Oslo: Kunnskapssenteret, 2012. www.kunnskapssenteret.no/ Nyheter/Ingen+dokumentasjon+for+en+ helsemessig+gevinst+av+tidlig+ultralyd. $14398 . \mathrm{cms}$ (23.3.2012).

10. Fredrikstad A. Tom har Downs: - Alle har rett til å leve. TV2-nyhetene 14.1. 2012. www.tv2.no/ nyheter/innenriks/tom-har-downs-alle-har-retttil-aa-leve-3682994.html (23.3.2012).

11. Salvesen KÅ. Ultrauklar bioteknologilov. Tidsskr Nor Lægeforen 2004; 124: 819-21.

12. Fetal Medicine Foundation. www. fetalmedicine $\mathrm{com} / \mathrm{fmf} /(23.3 .2012)$

13. Norsk gynekologisk forening. Veileder i fødsels hjelp 2008. www.legeforeningen.no/id/131701.0 (23.3.2012)

14. Solberg B. Informerte valg - viktig også for norske gravide. Tidsskr Nor Lægeforen 2009; 129: 1346-8.

Mottatt 24.1. 2012, første revisjon innsendt 30.3 2012, godkjent 26.4. 2012. Medisinsk redaktør Are Brean. 